\title{
The impact of government financial assistance on the performance and financing of Australian SMEs
}

\author{
Dong Xiang \\ International Institute for Financial Studies, Jiangxi University of Finance and \\ Economics, Nanchang, China \\ Andrew Worthington \\ Accounting, Finance and Economics Department, Griffith University, \\ Nathan, Australia
}

\begin{abstract}
Purpose - To examine the impact of government financial assistance provided to Australian small and medium-sized enterprises (SMEs).

Design/methodology/approach - Use firm-level panel data on more than two thousand SMEs over a five-year period from the Business Longitudinal Database compiled by the Australian Bureau of Statistics. We measure the impact of government financial assistance in terms of subsequent SME performance (income from sales of goods and services and profitability) and changes in the availability of alternative nongovernment finance.
\end{abstract}

Findings - We find government financial assistance helps SMEs improve performance over and above the effects of conventional financing. We also find than the implicit guarantee effect signalled by a firm receiving government financial assistance suggests firms are more likely to obtain nongovernment finance in the future. Control factors that significantly affect SME performance and finance availability include business size, the level of innovation, business objectives, and industry.

Research limitations - Nearly all of the responses in the original survey data are qualitative so we are unable to assess how the strength of these relationships varies by the levels of assistance, income, and profitability. Our measure of government financial assistance is also general in that it includes grants, subsidies, and rebates from any Australian government organization, so we are unable to comment on the impact of individual federal, state, or local government programs.

Practical implications - Government financial assistance helps SMEs improve both immediate and future performance as measured by income and profitability. This could be because government financial assistance quickly overcomes the financial constraints endemic in SMEs. Government financial assistance also helps SMEs obtain nongovernment finance in the future. We conjecture that this is because it overcomes some of the information opaqueness of SMEs.

Originality/value - Few studies focus on the impact of direct government financial assistance compared with indirect assistance as typical in credit guarantee schemes. We employ a very large and detailed dataset on Australian SMEs to undertake our analysis.

Keywords Small and medium-sized enterprises, Government financial assistance, Firm performance, Firm financing

Article Classification Research paper 


\section{Introduction}

Small and medium-sized enterprises (SMEs) generally lack sufficient finance and therefore require special attention because of their inherent informational opaqueness and limited finance sources available (e.g. Beck et al., 2005, 2008; Guiso and Minetti, 2010), with this imperfect ability to obtain finance often used to justify government intervention. Very often, government intervention has taken the form of financial assistance, with a concentration on direct subsidised credit programs and indirect credit guarantee schemes, with credit guarantee schemes particularly considered as a market-oriented strategy for improving SME performance and access to finance, and thereby business sustainability. However, there is some debate about the impact of these schemes with poor evidence of any additional or incremental effect (e.g. Riding et al., 2007; Vogel and Adams, 1997). In addition, there is some question as to whether the overall benefit of these programs exceeds their often-large costs (Craig et al., 2009).

Australia is one of very few countries without a credit guarantee scheme for small business loans. Instead, government policy in Australia supports SME financing using a number of forms of direct assistance, including tax benefits, grants, and subsidies. Consequently, there is a question about whether government financial assistance is effective in the absence of a credit guarantee scheme, especially during the recent global financial crisis (GFC) when many SMEs experienced additional restrictions in their access to finance because of the deterioration in domestic and international credit markets. One particular concern with direct financial assistance (government grants, funds and subsidies) is that it may lead to distortion in financial markets and encourage the excessive use of capital, fostering slow repayment, and allowing unprofitable firms to survive (Hallberg, 1999), leading to lower productivity in the sector.

Nonetheless, the general argument is that government financial assistance plays a role in easing SME financial constraints by helping generate additional cash flows and/or assisting SMEs to obtain finance. However, few studies, not least in Australia, focus on the impact of direct government financial assistance compared with indirect assistance, as typically involved in credit guarantee schemes. Drawing on these perspectives, we employ the Business Longitudinal Database (BLD) survey by the Australian Bureau of Statistics (ABS) to examine the impact of direct government financial assistance in Australia in two stages. In the first stage, we examine whether SMEs that received direct government financial assistance significantly improved their performance, as measured by income from the sale of goods and services and 
profitability. In the second stage, we examine whether a record of past government assistance assists SMEs in obtaining finance in the future.

The remainder of the paper is organised as follows. Section 2 briefly discusses the types of government financial assistance available to SMEs in Australia. Section 3 discusses the relevant literature. Section 4 details the sample and data and Section 5 presents the model specifications and variables. Section 6 discusses the results. Section 7 provides some concluding remarks.

\section{Government financial assistance to SMEs in Australia}

Australia is one of very few countries that have not introduced a credit guarantee scheme for small business loans, even during the GFC when many businesses experienced severe credit constraints. Instead, Australian governments provide a range of direct financial assistance packages, including grants, subsidies, and tax benefits, at the federal, state and territory, and local government level. At the federal level, tax benefits such as tax rebates and deductions play an important role in assisting SMEs. For example, under the R\&D Tax Credit Scheme, which replaced the R\&D Tax Concession in July 2010, small firms with turnover less than \$20 million are entitled to a 45 percent refundable tax credit and a 40 percent tax credit for companies with turnover of more than $\$ 20$ million. If a small business has an annual turnover of less than $\$ 2$ million, the business is eligible to claim a 50 percent bonus tax deduction for eligible assets costing \$1,000 or more purchased between 13 December 2008 and 13 December 2009 (Thomson, 2009). In addition, the government reduced quarterly pay-as-you-go instalments for small businesses during 2009-10, while if a SME finds it difficult to pay its tax debts, it can apply for interest-free payment arrangements to the government (Peskett, 2011).

Subsidies and grants at the federal level also target SMEs in particular aspects of business, especially exporting, innovation, start-up, and commercialisation. For example, if a SME has spent $\$ 10,000$ over two years on eligible export marketing expenses, the business is eligible for an Export Market Development Grant (EMDG), while the government provides Export Finance Guarantees (EFG) as an indemnity to lenders to lend directly to overseas buyers thus helping customers of Australian exporters. In 2010, the government launched Commercialisation Australia (CA) to supersede the previous and similar Commercialising Emerging Technologies (COMET) program, which becomes the primary source for Australian government assistance in helping to get ideas into the market place. Under this program, 
applicants at the proof of concept stage may be eligible for funding of up to $\$ 250,000$ and additional repayable assistance of up to $\$ 2$ million is available for early stage commercialisation activities (Peskett, 2011). To encourage the start-up of SMEs, the government also initiated an Early Stage Venture Capital Limited Partnerships (ESVCLP) Program aimed at stimulating Australia's early-stage venture capital sector. A venture capital fund registered as an ESVCLP receives flow-through tax treatment. Thus, investors in an ESVCLP are exempt from tax (AusIndustry, 2015).

The federal government also provides financial assistance to improve facilities and working environments for SMEs. For example, the government subsidizes SMEs through investing \$11.4 million in the Satellite Phone Subsidy Scheme. The federal government’s Clean Business Australian Program (CBAP) aims to assist SMEs in climate change issues. Under the CBAP program, the re-tooling scheme provides grants of between $\$ 10,000$ and $\$ 50,000$, up to a maximum of half of the cost of each project for businesses with turnover less than $\$ 100$ million. A building fund aimed at owners of existing commercial office buildings to encourage the retrofitting and commissioning of buildings, with grants ranging from $\$ 50,000$ to $\$ 500,000$ for up to $50 \%$ of project costs (Business.gov.au, 2015).

In addition, the federal government also provides a large variety of grants for SMEs in specific industries including agribusiness, manufacturing, and tourism. For example, the Textile, Clothing and Footwear (TCF) Small Business Program provides grants of up to $\$ 50,000$ for projects to improve the business enterprise culture of established businesses in this sector. Under the Clean Technology Investment Program, \$800 million in grants are to support Australian manufacturers to invest in energy efficient capital equipment and low-emission technologies, progresses and products. Finally, the TQUAL grant scheme provides grants of between $\$ 5000$ and $\$ 10,000$ for companies that develop “innovative tourism projects" (AusIndustry, 2015).

All state and territory governments in Australia also provide some financial assistance to SMEs in various forms. In New South Wales, the Payroll Tax Incentive Scheme provides payroll tax concessions to encourage new and existing businesses in locations where unemployment is above the state average. The Safety Solutions Rebate Program offers small business owners up to $\$ 500$ for identifying and implementing safety solutions in the workplace. In Queensland, the Business and Industry Transformation Incentives offers grants of $\$ 30,000$ to $\$ 250,000$ to companies with a new product, a $R \& D$ program, or a new process that can help transform key sectors such as aviation, biotechnology, IT, tourism, and processed foods. The 
Research Industry Partnerships Program provides grants of $\$ 200,000$ to $\$ 1$ million over one to three years to fund research projects between industry and research organisations. Queensland also provides State Government Emergency Assistance for locally owned small businesses affected by drought conditions, under which small businesses may be eligible to receive an interest subsidy of up to $50 \%$ payable on new or existing loans with a maximum interest subsidy of $\$ 10,000$ yearly for two years (Business.gov.au., 2015).

In South Australia (SA), the Bio Innovation SA Grants offers funds of $\$ 50,000$ to $\$ 250,000$ to assist biotechnology companies to do everything from market research and business development to purchasing equipment. The trainee Wage Payroll Tax Rebate encourages small businesses to employ trainees or apprentices. In Victoria, the state government provides grants of up to $\$ 10,000$ to help small businesses enter their first export market, and grants of up to $\$ 1.5$ million to help SMEs design products, processes and services to help meet the future technology needs of Victorian public sector entities. In Western Australia provides up to \$200 towards the cost of any form of training that will help to improve the productivity of a small business. Tasmania government provides grants of up to $\$ 50,000$ to help SMEs to identify, evaluate, and invest in projects or activities that will help them grow, and up to $\$ 150,000$ to cover the direct costs incurred by a business to commercialise a product or service. Lastly, the Northern Territory government provides up to $\$ 25,000$ to help businesses that can help deliver “positive regional economic development outcomes”, while the Canberra Business Development Fund is available to businesses as a source of capital funds through equity investment (Business.gov.au., 2015).

Finally, some local governments, mostly in capital cities, also provide limited financial assistance to SMEs. As examples, besides the Canberra Fund, the City of Perth offers cash grants of up to $\$ 2,000$ to small businesses located within the city. The City of Melbourne provides up to $\$ 30,000$ to support costs yet incurred by businesses established or being set up in Melbourne (Enterprise Melbourne, 2015). In addition, Frankston City Council in Melbourne provides grants of up to $\$ 10,000$ to start-up businesses in the region.

\section{Theoretical framework}

A sizeable literature focuses on the restricted capability of SMEs to obtain finance because of their inherent informational opacity (e.g. Beck et al., 2005, 2008; Berger and Udell, 2006; Guiso and Minetti, 2010; Dietrich, 2012). On one hand, SMEs are less likely to have access to 
direct finance through debt and equity markets, and thus rely heavily on intermediated finance, with banks and other financial institutions being the main source (Iturralde, et al., 2010). On the other, lenders may fail to allocate loans efficiently because lenders consider both the interest rate they will receive on a loan and its riskiness when deciding to lend. However, adverse selection arising from the presence of informational problems of SMEs can may it harder that an interest rate will emerge that suits both the available lenders and borrowers because adverse selection is a consequence of an environment in which lenders can only observe the risk characteristics of a pool of borrowers, but not those of any individual borrower. Under these circumstances, moral hazard can also make the situation worse, because higher interest rates may induce firms originally bearing lower risk to undertake riskier projects (Craig et al. 2009). Consequently, lenders such as banks may wish to have less exposure to SMEs or desire to charge SMEs higher fees and interest rates as compared with larger firms (Beck, et al., 2008), and SMEs have a severe lack of negotiation power (Dietrich, 2012), because the alternatives to bank finance are even more costly (Roberts and Sufi, 2009).

Arguably, these conditions of market failure potentially justify government intervention. Traditional approaches to financial assistance to SMEs have concentrated on direct subsidised credit programmes and indirect credit guarantee schemes. Compared with direct government assistance, credit guarantee schemes are considered a market-oriented strategy for improving SME access to financing and have been widely adopted by many countries to alleviate the problems SMEs face in seeking credit and achieving financial, and ultimately, economic, benefits (e.g. Boocock and Shariff, 2005; Chandler, 2012; Riding et al., 2007). However, some controversy surrounds credit guarantee schemes. De Rudy (2007) argues that banks could push SMEs into guaranteed loans as opposed to regular loans, because the guarantee makes the loan more profitable for the bank. Vogel and Adams (1997) identify two possible types of substitution effects which may arise from guarantee schemes and which are likely to lead to an overestimation of additionality or incrementality, namely, intra-portfolio substitution and interlender substitution.

The former arises when a lender transfers some or all the qualifying portion of its existing loan portfolio to the guarantee programme; the latter refers to the situation where banks operating under a guarantee scheme capture SMEs serviced by other banks. In addition, considering the administrative costs of the schemes, there is a question as to whether the benefits of the programs exceed their costs (Craig et al. 2009). One argument is that the guarantee schemes are indeed a continued flow of government subsidies disguised by the 
provision of free or low cost facilities and services as well as the secondment of staff from other government departments (Green, 2003). Therefore, the question should be asked whether guarantee schemes are the best way to help SME financing at the lowest possible social cost, because a more cost effective and efficient way to improve access to credit could be in the forms of training bank personnel in small business lending, direct grants or subsidies, or tax reduction, etc. (Green, 2003).

Possibly concerned with the ambiguous impact of credit guarantee schemes, governments in Australia have persistently refused to introduce one for SMEs. In addition, the alleged easing of the financial constraints faced by SMEs in Australia over time could implicitly imply the improved effectiveness of government financial assistance over a credit guarantee scheme. For instance, the survey used in our analysis found that the availability of finance increased by $80 \%$ in 2006 and 82\% in 2007 alone. Similarly, a survey by PwC/East \& Partners Business Barometer found that in 2010 only 37\% of small businesses expected credit to be constrained in the year ahead, compared to 82\% of the businesses surveyed in 2009 (RBA, 2011). Therefore, government financial assistance may also help ease SME financial constraints.

Theoretically, government financial assistance can assist SMEs in two main ways. First, financial assistance can help the business improve its performance and thus generate more cash flows, which is a direct way of easing any financial constraints. For example, Chandler (2012) found that the Canada Small Business Financing Program helped increase growth in salary, employment, and revenues by 12, 12 and 7 percentage points, respectively. We assume direct financial assistance may have a similar effect. Second, SMEs that have received government financial assistance are more likely to obtain finance from creditors or investors, similar to a guarantee effect. The intervention of government financial assistance can then help alleviate the impact of asymmetric information by either equalising the information available (Kon and Storey, 2003), or by enhancing the abilities and capacity for collateralised obligations (Liu et al., 2011). Consequently, we examine the impact of direct government financial assistance in two ways: first, whether it helps improve SME performance, and second, whether it enables SMEs to deal with the problem of information asymmetry so that they obtain access to other finance. Together, this helps us to gauge its effectiveness.

\section{Data}


In our analysis, we utilize the results of the surveys included in the Business Longitudinal Database (BLD) Expanded Confidentialised Unit Record File (CURF) conducted periodically by the Australian Bureau of Statistics (ABS). The ABS Business Characteristics Survey directly collects the data with the assistance of the Australian Taxation Office and Australian Customs. The BLD follows the earlier ABS development of a Business Longitudinal Survey, which ran from 1994 to 1999, based on which several studies investigated Australian small and medium-sized enterprises from different perspectives. Overall, the BLD aims to increase our understanding of the activities or factors that are relevant to business performance and the business characteristics associated with these activities and factors.

The BLD comprises two independent samples (referred to as panels) drawn from the inscope Australian SME populations, defined in the survey as businesses employing fewer than 200 persons. The panel used in this analysis contains five reference periods of data for financial years 2005-06, 2006-07, 2007-08, 2008-09, 2009-10 (for simplicity, we refer to these by the ending calendar year, i.e. 2005-2010). The sample includes approximately 2,732 SMEs in each of the survey years (note that the actual sample size varies by year because of survey dropouts and missing data) as selected from a survey frame created in June 2005 of the population of the then nearly 1.6 million Australian SMEs.

\section{Empirical models}

We employ a panel data model, which has several advantages over conventional cross-sectional or time-series models, as described by Baltagi (1995). The most significant advantage of the panel data model we use is that it allows us to control for heterogeneity. This feature is particularly important in our context as we are specifically interested in controlling for the presence of industry-specific effects in investigating the effects of government financial assistances on SME performance. In addition, a panel data model allows for the presence of dynamic effects, which are again important in this study as we wish to investigate the lagged effects of changing conditions.

Our data is a 'short panel' in the sense that there are a large number of cross-sections (2,735 firms) and just a few periods (5 years). The usual assumption is that a random effects model is then more applicable than, say, a fixed effects model. First, the fixed effects model strongly implies the non-random selection of sample firms from some larger population. This is not the case with our sample firms. Second, the random effects model is generally more efficient than 
a fixed effects model with short panels (Gujarati, 2007). Third, applying fixed effects model to a short panel involves an excessively large number of dummy variables (one for each firm). Finally, we already include a number of other firm-specific characteristics, such as industry, in our model as control variables. Specifying such time-invariant dummies in a fixed effects model always brings with it the possibility of severe multicollinearity, a situation made potentially worse with binary dependent variables, as here (Allison and Christakis, 2006).

To investigate the impact of government financial assistance, we employ two parameters, changes in income from the sale of goods and services and profitability, as measures of performance, and finance availability to examine whether government financial assistance can help SMEs access finance. With respect to the explanatory variables, in addition to the government financial assistance, we also include business objective variables and other control variables. Therefore, the logit random effects models for investigation into whether government financial assistance helps improve SME performance are set as follows:

$$
I N C_{i t}=\alpha+f_{i t}(G O V, O B J E C T I V E S, I N D U S T R Y, S Z E, G R O, E X P)+\varepsilon_{i t}
$$

and

$$
P R O_{i t}=\alpha+f_{i t}(G O V, O B J E C T I V E S, I N D U S T R Y, S Z E, G R O, E X P)+\varepsilon_{i t}
$$

where

INC takes a value of one if income from the sale of goods and services increased

PRO from the previous year, otherwise zero.

GOV

takes a value of one if profitability increased from the previous year, otherwise zero.

takes a value of one if the business received any financial assistance, including grants, subsidies and rebates, from Australian government organizations, otherwise zero.

OBJECTIVES are a series of business objective variables, FOF, FOC, FOO, FOQ, FOI, and $\mathrm{FOH}$, which take values of one (otherwise zero) for SMEs with a stated business focus in the corresponding category from among the options of finance measures (e.g. profits, sales, growth, returns on investments), cost measures (e.g. budget, cost per unit of output, inventory cost), operational measures (e.g. asset utilisation, on-time delivery), quality measures (e.g. customer satisfaction, defect rates), innovation measures (press innovations, new value added products), and human resources (e.g. job satisfaction, skills development), respectively.

INDUSTRY denotes 11 industry dummy variables representing the two-digit Australian and New Zealand Standard Industry Classification (ANZSIC) subdivisions of agriculture, mining, manufacturing, construction, wholesale trade, retail trade, accommodation, transport, communication services, property and business services, cultural and recreation services, and personal services i.e. IAG, IMA, ICO, IWH, IRE, IAC, ITR, ITE, IPR, ICU, IPE, respectively.

SIZE is the logarithm of total sales

GRO takes a value of one if the business introduced any new or significantly improved operational processes, otherwise zero.

EXP is the percentage of export sales to total sales 
We use the following model to examine whether government financial assistance alleviates problems with asymmetric information and thus help SMEs access finance:

$$
\text { FIN }_{i t}=\alpha+f_{i t}(G O V, O B J E C T I V E S, I N D U S T R Y, S Z E, G R O, E X P)+\varepsilon_{i t}
$$

where FIN is a dummy variable denoting whether SMEs obtain finance, otherwise zero, and all other variables are as previously defined.

In addition to the focus variables of INC, PRO, GOV, and FIN, we specify control variables. To start, business objectives closely relate to the outcome of SME performance. Given SMEs appear to be very different from large firms in terms of business operations (Ang, 1991), not all SMEs aim to seek significant growth. For example, mum-and-dad SMEs do not typically pursue a high-growth strategy (Berger and Udell, 1998). Instead, the owners of SMEs like these may merely enjoy operating the SME itself (Vos et al., 2007). It is therefore likely that desires for independence and control are keys reasons for the differences in SME financial behaviour (Curran, 1986). In the survey, there are six options available under the question "To what extent did this business focus on the following when assessing overall business performance.” The options are "finance measures (e.g. profits, sales, growth, returns on investments), cost measures (e.g. budget, cost per unit of output, inventory cost), operational measures (e.g. asset utilisation, on-time delivery), quality measures (e.g. customer satisfaction, defect rates), innovation measures (press innovations, new value added products), and human resources (e.g. job satisfaction, skills development). The questions in the survey concerning business focus are not mutually exclusive. We use this information to define six dummy variables (FOF, FOC, FOO, FOQ, FOI, and FOH), to indicate SMEs with a stated business focus in each category.

Several studies also suggest the importance of industry in determining firm performance and financing patterns (e.g., Caneghem and Campenhout, 2012; Degryse et al., 2012). For example, Ballakrishnan and Fox (1993) conclude that firm effects explain 52 percent of capital structure variation and inter-industry differences another 11 percent, while Van der Wijst (1989) finds that the manufacturing industry is capital intensive and requires large investments in fixed assets derived from both debt and equity, while the retail sector needs relatively less short-term debt. In Australian work, Romano et al. (2000) observes that firms in the services industry are less likely to use family loans, whereas family businesses in the manufacturing industry are less likely to use capital and retained profits. 
Figure 1 depicts the performance and financial activities of the sampled SMEs by industry. With respect to performance (as measured by whether profit and income from the sale of goods and services increased over the previous period), the wholesale industry was the best performer in the sample period followed by the transport and personal services industries; firms in the agriculture and communication services industries were generally the poorest performers during the period. Agriculture and transport recorded the receipt of more government financial assistance and normal financial activities, whereas the communication services industry received the least. To reflect these industry level factors, we create industry dummy variables (IAG, IMA, ICO, IWH, IRE, IAC, ITR, ITE, IPR, ICU, IPE) using the two-digit Australian and New Zealand Standard Industry Classification (ANZSIC) subdivisions of agriculture, mining, manufacturing, construction, wholesale trade, retail trade, accommodation, transport, communication services, property and business services, cultural and recreation services, and personal services, respectively.

Firm size (SIZE) can also influence the performance and financing of SMEs. The variable used to control for firm size is the logarithm of sales. Smaller SMEs are supposed to have less capacity to employ formal operating structures or systems, and less likely to get expensive professional consultation and advice as compared to their larger counterparts. In addition, they could be more serious in informational asymmetry. Thus, we assume larger SMEs are both more profitable and more likely to obtain finance.

Innovation-defined as the process of the adoption of internally or externally generated devices, systems, policies, programs, processes, products or services that are new to the adopting organization — can be treated as a proxy for growth opportunities (Rosenbusch et al., 2010). The influence of growth opportunities (GRO) on a firm's finance decision-making has been widely discussed. This reveals that by reducing debt, firms with growth opportunities may avoid the shareholder-creditor conflict in which the benefits can transferred from shareholders to creditors (Myers, 1977; Jensen and Meckling, 1976). Therefore, a firm with growth opportunities may be riskier (Fama and French, 2002). However, given the assumption that SMEs face financing constraints, those with growth opportunities are more likely to exhaust internal funds and require external funds. In combination with the traditional concern of SMEs with control and independence, SMEs with growth opportunities may seek external debt instead of external equity. As a result, the influence of growth opportunities on SMEs finance availability can be positive (e.g., Riding et al., 2007; Degryse et al., 2012). Lastly, exporting can also be associated with growth ambitions and therefore exporting can affect performance. 
Exporters are also more likely to have loan applications turned down because of heightened risk exposure to foreign markets (Riding et al., 2007). In our analysis, EXP is the ratio of export sales to total sales.

\section{$<$ TABLE I HERE $>$}

Table I provides summary statistics for the variables used in the analysis. About 24.2 percent of the SMEs are from the agriculture, forestry, and fishing industry. The second-largest group of SMEs in the sample is in the manufacturing industry (16.2 percent) while the third-largest sample group of SMEs is from the wholesale trade industry (10.3 percent). About 39 and 30.4 percent of SMEs considered they had increased income and profits compared with the previous year, respectively. About 18.6 percent received government financial assistance and 17.9 percent sought the normal finance during the period. Interestingly, only 39.4 percent of observations regarded financial measures, such as profits, sales growth, and returns on investments, as a major indicator of intended business performance. However, the SMEs appear to pay increasingly more attention to quality measures, the frequency of which was up to 40.6 percent. Nonetheless, 33.5 percent of the observations introduced new goods, services, or processes during the sample period.

\section{Results and discussion}

We first examine whether SMEs that received direct government financial assistance (including grants, subsidies, and rebates) significantly improved performance. We then examine whether government financial assistance helped SMEs obtain financing. To start with, given businesses sometimes receive government financial assistance such as tax rebates, subsidies, or grants toward the end of the year it could affect business performance in the following year(s). Model 2 is used to investigate the lagged effects, that is, whether the government assistance received in year $t-1$ has a significant effect on the performance of the business in year $t$. However, as discussed, SMEs have a restricted capacity to obtain finance because of their inherent informational opacity, thus financial constraints may negatively affect the business's performance. Put differently, the financing such as borrowing and equity obtained by SMEs may alleviate the possible financial constraints thus help improve the performance. As a comparison, we use Model 3 to examine the effects of normal financing that is, financing other than involved in government financial assistance, on firm performance. 
As discussed, the data in the analysis comprise a panel of 2,732 SMEs over the five-year period from 2005 to 2010 (potentially 13,660 firm-year observations). Unfortunately, because of incorrect sequencing, more than one tick for a tick-one question, or respondent omissions, there are a large number of missing observations in the panel. These vary across the unbalanced panel data models depending on the variables employed. For example, Model 1 has 10,300 firm-year observations. In contrast, Models 2 and 3 include only 7,235 observations because of the specification of lagged terms (only four years of data are used). It is possible that at least some of the missing data could relate to failed firms, thereby implying a survivorship bias, but we have no means of identifying whether this is the case.

\section{$<$ TABLE II HERE $>$}

We use variance inflation factors (VIFs) to assess the likelihood of multicollinearity. Given the largest VIF of 3.01 (FOC) and the mean VIF of 1.86 are both much less than the usual rule of thumb of VIF $>10$, we consider that the likelihood of significant multicollinearity is small. Table II details the estimated coefficients, standard errors, and marginal effects of the three separate models based on the panel date over the period 2005-10, where the upper panel presents the results of the models with income as the dependent variable and the lower panel provides the results of the models with profitability as the dependent variable. The loglikelihood ratio suggests the overall significance of the results of the logistic random panel data analyses. In Model 1, government financial assistance has a significant positive effect on firm income and profitability, with a firm receiving government financial assistance having an increase in the probability of higher income of $4.6 \%$ and profitability of $2.5 \%$. This effect is also significant in Model 2 where we lag government assistance by one year.

In Model 3, new borrowings or equity do not show a significant and positive effect on firm performance in the same year of obtaining finance. However, there is a significant and positive effect on the performance measured by income and profitability in the following year. That is, a firm that obtained financing could improve its income and profitability in the following year by $1.9 \%$ or $2.0 \%$ respectively. This result appears to lies opposite to that in Model 2 where government financial assistance only positively affected performance in current year not the following year. Our intuition is as follows. We assume the government financial assistance is a form of emergency funding. That is, the SMEs that received the government assistance are more likely to have experienced financial constraints prior to the assistance. These constraints may arise from a lack of funds for short-term and small investments and even working capital. 
Therefore, a relatively small amount of financial assistance could do the job of easing current financial constraints, as reflected by the improvement in performance.

\section{$<$ TABLE III HERE $>$}

In the second part of the analysis, we specified three models to examine whether government financial assistance helped SMEs obtain financing in the form of a "guarantee effect” and/or “information asymmetry-dispelling effect.” Table III provides the results for the three models. Without lags, government financial assistance has a significant and positive effect on the probability obtaining finance of 3.6\% (Model 1). In Model 2 with a one-year lag, government financial assistance also has a significant effect on the probability of obtaining finance in the current year that is significant at the $10 \%$ level, but this increases in statistical significance in the following year to the $1 \%$ level. In Model 3, when a two-year lag is included, government financial assistance no longer has a significant effect on the probability of obtaining finance in the current year. However, the effect of the one-year lagged government financial assistance remains significant with a marginal effect of a $2.0 \%$ increase in the probability of obtaining finance the year before. However, there is no significant effect of government financial assistance on the probability of obtaining finance after two years. Accordingly, the guarantee effect appears more effective in obtaining finance only in the following year.

With respect to the control variable, the business focus dummies have a significant effect on both the performance and the availability of the finance for the SME. For instance, SMEs whose focus lies on financial measures, including profits and ROA, experience an increase in the probability of increasing income and profitability and obtaining finance (with Model 1) by 9.8\%, 2.5\% and 3.1\%, respectively. SMEs that focus on cost and human resources measures are also more likely to obtain finance by between $1.1 \%$ and $1.6 \%$. However they appear not to have a consistent and significant effect on SME performance, which is consistent with the assumption that firms that focus on profits or growth are more like to pursue improvements in performance as compared with firms with non-profit or non-growth benchmarks.

Size consistently and significantly exerts positive effects on performance and financial availability. First, larger SMEs are more likely to better organised, more likely to implement new projects, introduce new technologies, obtain more funds, and seek access to professional consultants etc. Another reason could lie in the difference in business objectives. Larger firms are more business-focused; in contrast, smaller businesses may be more lifestyle-focused, and 
therefore seek business stability rather than profit-maximisation. The positive effect of size on finance-availability is consistent with existing studies because larger firms are able to provide more collateral, and have fewer informational problems than smaller firms (e.g. Beck, et al., 2008; Dietrich, 2012).

Unsurprisingly, innovation has a positive effect on income and profitability. Firms that introduced new products, operations, or methods during the year are more likely to increase the probability of an increase in income and profit by $12.9 \%$ and $14.4 \%$, respectively. Innovation also has a significant and positive effect on finance availability. As discussed, innovation is normally risky, such that firms that intend to introduce innovations are able to bear more risk (Fama and French, 2002). However, SMEs have very limited financing sources and rely more on internal finance for equity and relationship banking for debt (e.g. Berger and Udell, 1998; Beck et al., 2005). Therefore, firms with innovative projects are more likely to seek finance through these two channels. Moreover, internal finance and strong relationship banking can help alleviate project risk. Thus, the SMEs that introduced innovations are more likely to obtain finance than other SMEs.

Lastly, among the industry dummies, agricultural firms are less likely to improve their incomes and profits compared to firms in other industries. However, they are more likely to obtain finance. This is perhaps a reflection of the nature of agricultural firms. While their performance (as measured by income and profitability) is lower, they are invariably capitalintensive with large amounts of assets available to serve as collateral for the necessary borrowing. For the similar reason, mining firms are also more likely to obtain finance with a marginal effect of between $5.7 \%$ and $6.1 \%$.

\section{Concluding remarks}

Australia is one of very few countries without a small business credit guarantee scheme. Instead, Australian SMEs have been supported using direct forms of assistance, including tax benefits, finance assistance, and paid-for advice. In this study, based on the Business Longitudinal Database (BLD) survey by the Australian Bureau of Statistics (ABS), we employ panel data analysis to examine the impact of direct government financial assistance. In the first stage, we use three models to examine whether government financial assistance generally helps improve the income and profitability of SMEs. In the second stage, we consider whether government 
financial assistance helps address the problem of information asymmetry found when SMEs attempt to secure finance.

We found government financial assistance helps SMEs improve performance. That is, a firm that received government financial assistance increased its probability of improved income or profitability in the current year by $4.6 \%$ and $2.5 \%$, respectively. This contrasted with the effect of normal financing such as new equity or borrowings excepting government assistance, which only affected performance the following year. This could be because SMEs that received government assistance were more likely to have had financial constraints before the assistance. These constraints may arise from the lack of funds for short-term and small investments or even from lack of working capital. Therefore, a relatively small amount of financial assistance could adequately ease existing financial constraints.

In the second stage, we found that a firm receiving government financial assistance was more likely to obtain other finance in the following year by between $3.1 \%$ and $3.6 \%$. This provides some evidence that government financial assistance can help alleviate the informational problem endemic in small business. Lenders then either act as a free rider by using the information on intrinsic business quality provided by governments in extending assistance, or treat the government assistance as a form of collateral, both making it more likely that they will lend funds to SMEs receiving government financial assistance. The lagged effect of the government guarantee on obtaining finance could imply that investors and lenders may decide whether to invest in or lend to SMEs based on their prior success in receiving government financial assistance before providing them with funds.

In terms of ancillary findings, SMEs whose focus lay on financial measures, including profits and ROA, are more likely to improve their incomes, profitability, and chances of obtaining finance by between $6.4 \%$ to $9.8 \%, 4.3 \%$ to $5.1 \%$, and $2.7 \%$ to $3.1 \%$, respectively. In addition, SMEs that focus on cost and human resources measures are more likely to obtain finance, while larger firms are more likely improve performance. Innovation also has a positive effect on income, profitability, and finance availability. Finally, agricultural firms are less likely to improve their incomes and profits compared to firms in the other industries, but are more likely to obtain finance, possibly because of the better access to collateral.

The policy recommendations of our study appear reasonably obvious. While it is not possible to compare direct and indirect government financial assistance in this particular context, we have at least established that direct government financial assistance improves the 
income and profitability of SMEs. This provides a broad but quite powerful justification for these programs. In addition, we found that government financial assistance performs an important role in overcoming the information asymmetry that prevails in SMEs, and which can account for their credit constraints. This suggests governments could contemplate a more direct role in assessing the creditworthiness of SMEs as an independent third party to loan transactions, not as a funder as with a conventional credit guarantee, rather as a noncommercial facilitator in much the same way as a ratings agency.

\section{References}

Allison, P.D. and Christakis, N.A. (2006), "Fixed effects methods for the analysis of non-repeated events", Sociological Methodology, Vol. 36, No. 1, pp. 155-172.

Ang, J. (1991), "Small business uniqueness and the theory of financial management”, Journal of Small Business Finance, Vol. 37, No. 1, pp. 219-226.

AusIndustry (2015), "Early stage venture capital limited partnerships program”, available at http://www.ausindustry.gov.au/Pages/default.aspx (accessed 26 May 2015).

Ballakrishnan, S. and Fox, I. (1993), "Asset specificity, firm heterogeneity and capital structure”, Strategic Management Journal, Vol. 14, No. 1, pp. 3-16.

Baltagi, B. (1995), Economics Analysis of Panel Data, Wiley, Chichester.

Beck, T., Demirguc-Kunt, A. and Maksimovic, V. (2005), "Financial and legal constraints to firm growth: Does size matter?”, Journal of Finance, Vol. 60, No. 1, pp. 137-177.

Beck, T., Demirguc-Kunt, A. and Maksimovic, V. (2008), "Financing patterns around the world: Are small firms different?”, Journal of Financial Economics, Vol. 89, No. 3, pp. 467-487.

Berger, A.N. and Udell, G.F. (1998), "The economics of small business finance: The roles of private equity and debt markets in the financial growth cycle”, Journal of Banking and Finance, Vol. 22, No. 6-8, pp. 613-673.

Berger, A.N. and Udell, G.F. (2006), “A more complete conceptual framework for SME finance”, Journal of Banking and Finance, Vol. 30, No. 11, pp. 2945-2966.

Boocock, G. and Shariff, M.N.M. (2005), "Measuring the effectiveness of credit guarantee schemes: Evidence from Malaysia”, International Small Business Journal, Vol. 23, No. 4, pp. 427-454.

Business.gov.au. (2015) available at http://www.business.gov.au/ (accessed 24 May 2015)

Caneghem, T.V. and Campenhout, G.V. (2012), "Quantity and quality of information and SME financial structure”, Small Business Finance, Vol. 39, No. 2, pp. 341-358.

Chandler, V. (2012), "The economic impact of the Canada small business financing program”, Small Business Economics, Vol. 39, No. 1, pp. 253-264.

Craig, B.R., Jackson, W.E. and Thomson, J.B. (2009), "The economic impact of the small business administration's intervention in the small firm credit market: A review of the research literature”, Journal of Small business Management, Vol. 47, No. 2, pp. 221-231.

Curran, J. (1986), Bolton Fifteen Years On: A Review and Analysis of Small Business Research in Britain 19711986, Small Business Research Trust, London.

Degryse, H., Goeij, P.D. and Kappert, P. (2012), “The impact of firm and industry characteristics on small firms' capital structure”, Small Business Economics, Vol. 38, No. 4, pp. 431-447.

De Rudy, V. (2007), “The SBA’s justification IOU”, Regulation, Spring, pp. 26-34 
Dietrich, A. (2012), "Explaining loan rate differentials between small and large companies: Evidence from Switzerland, Small Business Economics, Vol. 38, No. 4, pp. 481-494.

Enterprise Melbourne (2015), “Small business grants” available at http://www.melbourne.vic.gov.au/enterprisemelbourne/businesssupport/grantssponsorship/grants/Pages/Bu sinessGrants.aspx (accessed 24 May 2015).

Fama, E.F. and French, K.R. (2002), “Testing trade-off and pecking order predictions about dividends and debt”, Review of Financial Studies, Vol. 15, No. 1, pp. 1-33.

Green, A. (2003), “Credit guarantee schemes for small enterprises: An effective instrument to promote private sector-led growth?”, SME Technical Working Paper, No. 10. Vienna, UNIDO.

Guiso, L. and Minetti, R. (2010), “The structure of multiple credit relationships: Evidence from U.S firms”, Journal of Money, Credit and Banking, Vol. 42, No. 6, pp. 1037-1071.

Gujarati, D.N. (2007). Basic Econometrics, $4^{\text {th }}$ Ed., McGraw-Hill, New Delhi.

Hallberg, K. (1999), “A market-oriented strategy for small and medium-scale enterprises”, Discussion Paper No. 40, International Finance Corporation, Washington, D.C.

Iturralde, T., Maseda, A. and San-Jose, L. (2010), "Empirical evidence of banking relationships for Spanish SMEs”, International Small Business Journal, Vol. 28, No. 3, pp. 274-295.

Jensen, M.C. and Meckling, W.H. (1976), "Theory of the firm: Managerial behaviour, agency costs, and ownership structure”, Journal of Financial Economics, Vol. 3, No. 4, pp. 305-360.

Kon, Y. and Storey, D.J. (2003), “A theory of discouraged borrowers”, Small Business Economics, Vol. 21, No. 1, pp. 31-49.

Liu, M.H., Margaritis, D. and Tourani-Rad, A. (2011), “Asymmetric information and price competition in small business lending”, Journal of Banking and Finance, Vol. 35, No. 9, pp. 2189-2196.

Myers, S. C. (1977), “Determinants of corporate borrowing”, Journal of Financial Economics, Vol. 5, No. 1, pp. 147-175.

Peskett, M. (2011), “Don’t be afraid to grab a grant”, available at http://www.startupsmart.com.au/funding/dontbe-afraid-to-grab-a-grant/201101271463.html (accessed 24 May 2015).

Reserve Bank of Australia (2011), "Submission to the Inquiry into Access for Small and Medium Business to Finance”, available at http://www.rba.gov.au/publications/submissions/inquiry-access-small-med-fin0211.html_(accessed 24 May 2015).

Riding, A., Madill, J. and Haines, G. (2007), “Incrementality of SME loan guarantees”, Small Business Economics, Vol. 29, No. 1, pp. 47-61.

Roberts, M.R. and Sufi, A. (2009), “Control rights and capital structure: An empirical investigation”, Journal of Finance, Vol. 64, No. 4, pp. 1657-1695.

Romano, C.A., Tanewski, G.A. and Smyrnios, K.X. (2000), "Capital structure decision making: A model for family business”, Journal of Business Venturing, Vol. 16, No. 3, pp. 285-310.

Rosenbusch, N., Brinckmann, J. and Bausch, A. (2011), "Is innovation always beneficial? A meta-analysis of the relationship between innovation and performance in SMEs”, Journal of Business Venturing, Vol. 26, No. 4, pp. 441-457.

Thomson, J. (2009), “30 Government grants to grow your business”, available at http://www.smartcompany.com.au/start-up/20090728-30-government-grants-to-grow-your-business.html (accessed 24 May 2015).

Van der Wijst, D. (1989), Financial Structure in Small Business: Theory, Tests, and Applications, Berlin: Springer-Verlag.

Vogel, R. and Adams. D. (1997), “Costs and benefits of loan guarantee programs”, The Financier, Vol. 4, pp. 2229.

Vos, E., Yeh, A.J.Y., Carter, S. and Tagg, S. (2007), “The happy story of small business financing”, Journal of Banking and Finance, Vol. 31, No. 9, pp. 2648-2672. 
Zajac, S., Ireland, D. and Hitt, M. (2000), "International expansion by new venture firms: International diversity, mode of market entry, technological learning, and performance”, Academy of Management Journal, Vol. 43, No. 5, pp. 925-950. 


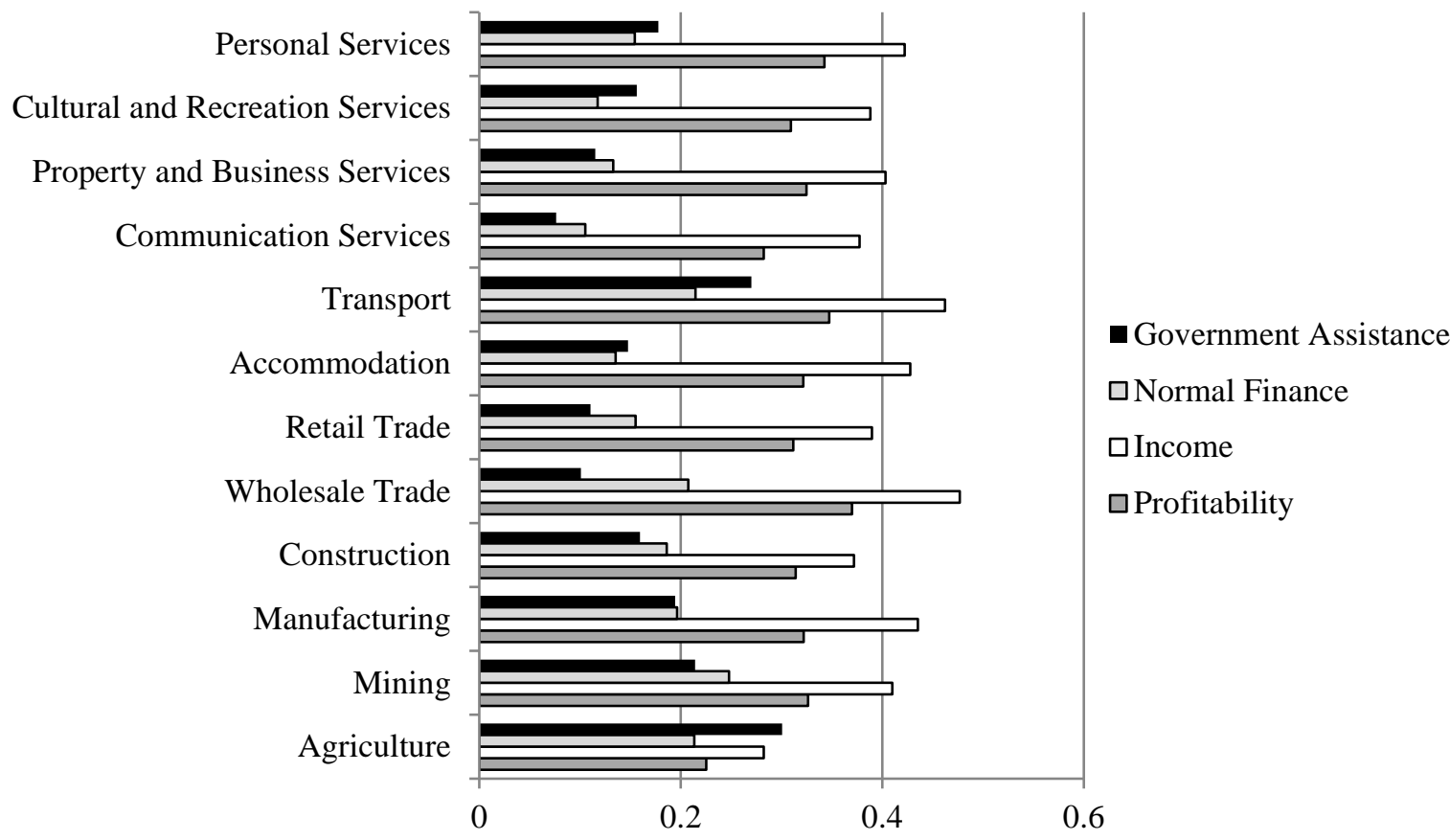

Figure 1. Proportion of SMEs receiving government assistance and normal (nongovernment) finance, and reporting improved performance (income and profitability) by industry 
Table I. Variable definitions

and statistics

\begin{tabular}{|c|c|c|c|}
\hline Variables & Definition & Mean & Std. dev. \\
\hline INC & Equals one if income from sale of goods and services increased from previous year; zero otherwise. & 0.390 & 0.487 \\
\hline PRO & Equals one if profitability increased from previous year; zero otherwise. & 0.304 & 0.460 \\
\hline FIN & Equals one if obtained finance; zero otherwise & 0.179 & 0.384 \\
\hline GOV & $\begin{array}{l}\text { Equals one if the business received any financial assistance including grants, subsidies and rebates from } \\
\text { Australian government organizations; zero otherwise. }\end{array}$ & 0.186 & 0.389 \\
\hline FOF & Equals one if the business focus is on financial measures; zero otherwise. & 0.394 & 0.488 \\
\hline FOC & Equals one if the business focus is on cost measures; zero otherwise. & 0.321 & 0.467 \\
\hline FOO & Equals one if the business focus is on operational measures; zero otherwise. & 0.233 & 0.423 \\
\hline FOQ & Equals one if the business focus is on quality measures; zero otherwise. & 0.406 & 0.491 \\
\hline FOI & Equals one if the business focus is on innovation measures; zero otherwise. & 0.138 & 0.345 \\
\hline $\mathrm{FOH}$ & Equals one if the business focus is human resource measures; zero otherwise. & 0.146 & 0.353 \\
\hline IAG & Equals one if the firm is in agriculture industry; zero otherwise. & 0.242 & 0.423 \\
\hline IMA & Equals one if the firm is in mining industry; zero otherwise. & 0.042 & 0.201 \\
\hline ICO & Equals one if the firm is in manufacturing industry; zero otherwise. & 0.162 & 0.373 \\
\hline IWH & Equals one if the firm is in construction industry; zero otherwise. & 0.052 & 0.221 \\
\hline IRE & Equals one if the firm is in wholesale trade industry; zero otherwise. & 0.103 & 0.302 \\
\hline IAC & Equals one if the firm is in retail trade industry; zero otherwise. & 0.062 & 0.251 \\
\hline ITR & Equals one if the firm is in accommodation and restaurant industry; zero otherwise. & 0.073 & 0.253 \\
\hline ITE & Equals one if the firm is in transport industry; zero otherwise. & 0.062 & 0.241 \\
\hline IPR & Equals one if the firm is in communication services industry; zero otherwise. & 0.052 & 0.213 \\
\hline ICU & Equals one if the firm is in property industry; zero otherwise. & 0.062 & 0.232 \\
\hline IPE & Equals one if the firm is in cultural and recreational services industry; zero otherwise. & 0.053 & 0.223 \\
\hline SZE & Total sales in thousands of dollars & 2678.302 & 8707.822 \\
\hline GRO & Equals one if business introduced new or improved operational processes; zero otherwise. & 0.335 & 0.472 \\
\hline EXP & Percentage of export sales in total sales & 0.061 & 0.938 \\
\hline
\end{tabular}


Table II. SME performance and government financial

assistance

\begin{tabular}{|c|c|c|c|c|c|c|c|c|c|}
\hline \multirow[b]{2}{*}{ Variable } & \multicolumn{3}{|c|}{ Model 1} & \multicolumn{3}{|c|}{$\begin{array}{c}\text { Model } 2 \\
\text { Dependent variable = INC }\end{array}$} & \multicolumn{3}{|c|}{ Model 3} \\
\hline & Coef. & SE & $\begin{array}{c}\text { Marginal } \\
\text { effect }\end{array}$ & Coef. & $\mathrm{SE}$ & $\begin{array}{c}\text { Marginal } \\
\text { effect }\end{array}$ & Coef. & $\mathrm{SE}$ & $\begin{array}{c}\text { Marginal } \\
\text { effect }\end{array}$ \\
\hline Cons. & $-1.540^{* * *}$ & 0.133 & & $-1.599^{* * *}$ & 0.208 & & $-1.579^{* * *}$ & 0.208 & - \\
\hline GOV & $0.225^{* * *}$ & 0.070 & 0.046 & $0.407^{* * *}$ & 0.118 & 0.042 & - & - & - \\
\hline GOV $(t-1)$ & - & - & - & -0.083 & 0.117 & - & - & - & - \\
\hline FIN & - & - & - & - & - & - & 0.160 & 0.113 & - \\
\hline FIN (t-1) & - & - & - & - & - & - & $0.229^{* *}$ & 0.110 & 0.019 \\
\hline FOF & $0.416^{* * *}$ & 0.036 & 0.098 & $0.376^{* * *}$ & 0.063 & 0.073 & $0.374^{* * *}$ & 0.063 & 0.064 \\
\hline FOC & $-0.085^{* *}$ & 0.038 & -0.066 & -0.091 & 0.065 & & -0.084 & 0.065 & - \\
\hline FOO & $-0 . .019$ & 0.031 & - & -0.008 & 0.052 & & -0.007 & 0.052 & - \\
\hline FOQ & 0.057 & 0.087 & - & 0.035 & 0.081 & & 0.021 & 0.047 & - \\
\hline FOI & $0.072^{* *}$ & 0.033 & 0.008 & 0.080 & 0.053 & & 0.081 & 0.053 & - \\
\hline $\mathrm{FOH}$ & $0.091^{* * *}$ & 0.032 & 0.011 & 0.047 & 0.055 & & 0.054 & 0.055 & - \\
\hline IAG & $-0.692^{* * *}$ & 0.139 & -0.128 & $-0.658^{* * *}$ & 0.214 & -0.122 & $-0.610^{* * *}$ & 0.212 & -0.117 \\
\hline IMA & -0.066 & 0.196 & - & -0.176 & 0.297 & - & -0.143 & 0.296 & - \\
\hline ICO & -0.359 & 0.142 & - & -0.069 & 0.259 & - & -0.071 & 0.215 & - \\
\hline IWH & -0.190 & 0.175 & - & 0.141 & 0.236 & - & -0.213 & 0.259 & - \\
\hline IRE & 0.050 & 0.157 & - & -0.221 & 0.242 & - & 0.101 & 0.235 & - \\
\hline IAC & -0.189 & 0.160 & - & -0.014 & 0.256 & - & -0.255 & 0.242 & - \\
\hline ITR & 0.016 & 0.168 & - & 0.087 & 0.263 & - & -0.007 & 0.236 & - \\
\hline ITE & 0.035 & 0.187 & - & -0.302 & 0.282 & - & 0.108 & 0.263 & - \\
\hline IPR & 0.035 & 0.184 & - & 0.018 & 0.256 & - & -0.332 & 0.282 & - \\
\hline ICU & -0.099 & 0.171 & - & -0.063 & 0.248 & - & 0.004 & 0.255 & - \\
\hline IPE & -0.208 & 0.167 & - & -0.053 & 0.089 & - & -0.067 & 0.248 & - \\
\hline SIZE & $0.018^{* * *}$ & 0.032 & 0.065 & $0.015^{* * *}$ & 0.039 & 0.069 & $0.016^{* * *}$ & 0.041 & 0.071 \\
\hline GRO & $0.591^{* * *}$ & 0.058 & 0.144 & $0.610^{* * *}$ & 0.094 & 0.143 & $0.623^{* * *}$ & 0.094 & 0.129 \\
\hline EXP & 0.022 & 0.034 & - & 0.129 & 0.166 & - & 0.132 & 0.179 & - \\
\hline Obs. & 10,300 & - & - & 7,235 & - & - & 7,235 & - & - \\
\hline \multirow[t]{2}{*}{$\log L$} & $301.251^{* * *}$ & - & - & $181.080^{* * *}$ & - & - & $181.520^{* * *}$ & - & - \\
\hline & \multicolumn{9}{|c|}{ Dependent variable $=$ PRO } \\
\hline Cons. & $-2.056^{* * *}$ & 0.137 & - & $-2.116^{* * *}$ & 0.211 & - & $-2.144^{* * *}$ & 0.210 & - \\
\hline GOV & $0.187^{* * *}$ & 0.071 & 0.025 & $0.382^{* * *}$ & 0.118 & 0.025 & - & - & - \\
\hline
\end{tabular}




\begin{tabular}{|c|c|c|c|c|c|c|c|c|c|}
\hline GOV (t-1) & - & - & - & -0.024 & 0.119 & & - & - & - \\
\hline FIN & - & - & - & - & - & - & 0.084 & 0.113 & \\
\hline FIN $(t-1)$ & - & - & - & - & - & - & $0.205^{* *}$ & 0.111 & 0.020 \\
\hline FOF & $0.471^{* * *}$ & 0.387 & 0.046 & $0.482^{* * *}$ & 0.065 & 0.043 & $0.480^{* * *}$ & 0.065 & 0.051 \\
\hline FOC & $-0.097^{* *}$ & 0.039 & -0.009 & -0.081 & 0.067 & - & -0.070 & 0.066 & - \\
\hline FOO & -0.010 & 0.033 & - & -0.022 & 0.053 & - & -0.021 & 0.053 & - \\
\hline FOQ & $0.067^{*}$ & 0.083 & 0.052 & 0.078 & 0.241 & 0.053 & 0.059 & 0.121 & - \\
\hline FOI & $0.097^{* * *}$ & 0.034 & 0.055 & 0.091 & 0.054 & - & $0.091^{*}$ & 0.054 & 0.057 \\
\hline $\mathrm{FOH}$ & $0.115^{* * *}$ & 0.034 & 0.037 & 0.021 & 0.055 & - & 0.031 & 0.055 & - \\
\hline IAG & $-0.627^{* * *}$ & 0.141 & -0.032 & $-0.554^{* * *}$ & 0.212 & -0.035 & $-0.500^{* *}$ & 0.210 & -0.039 \\
\hline IMA & 0.754 & 0.199 & - & -0.166 & 0.296 & - & -0.128 & 0.295 & - \\
\hline ICO & -0.178 & 0.144 & - & -0.194 & 0.213 & - & -0.189 & 0.212 & - \\
\hline IWH & -0.575 & 0.176 & - & -0.091 & 0.256 & - & -0.094 & 0.256 & - \\
\hline IRE & -0.009 & 0.158 & - & -0.002 & 0.232 & - & -0.039 & 0.231 & - \\
\hline IAC & -0.171 & 0.162 & - & -0.181 & 0.241 & - & -0.217 & 0.239 & - \\
\hline ITR & -0.127 & 0.171 & - & -0.065 & 0.255 & - & -0.057 & 0.254 & - \\
\hline ITE & -0.066 & 0.181 & - & -0.155 & 0.262 & - & -0.125 & 0.261 & - \\
\hline IPR & -0.107 & 0.189 & - & -0.025 & 0.278 & - & -0.059 & 0.278 & - \\
\hline ICU & -0.081 & 0.173 & - & -0.192 & 0.256 & - & -0.204 & 0.256 & - \\
\hline IPE & -0.202 & 0.169 & - & -0.017 & 0.246 & - & -0.021 & 0.210 & - \\
\hline SIZE & $0.031^{* *}$ & 0.175 & 0.025 & $0.025^{* * *}$ & 0.018 & 0.024 & $0.026^{* * *}$ & 0.019 & 0.028 \\
\hline GRO & $0.488^{* * *}$ & 0.059 & 0.167 & $0.555^{* * *}$ & 0.094 & 0.153 & $0.570^{* * *}$ & 0.094 & 0.162 \\
\hline EXP & 0.014 & 0.013 & - & -0.046 & 0.127 & - & -0.043 & 0.119 & - \\
\hline Obs. & 10,300 & - & - & 7,235 & - & - & 7,235 & - & - \\
\hline LR & $248.724^{* * *}$ & - & - & $152.793^{* * *}$ & - & - & $152.591^{* * *}$ & - & - \\
\hline
\end{tabular}


Table III. SME finance availability and government financial

assistance

\begin{tabular}{|c|c|c|c|c|c|c|c|c|c|}
\hline & \multicolumn{3}{|c|}{ Model 1} & \multicolumn{3}{|c|}{$\begin{array}{c}\text { Model } 2 \\
\text { Dependent variable }=\text { FIN }\end{array}$} & \multicolumn{3}{|c|}{ Model 3} \\
\hline & Coef. & SE & $\begin{array}{c}\text { Marginal } \\
\text { effect }\end{array}$ & Coef. & SE & $\begin{array}{c}\text { Marginal } \\
\text { effect }\end{array}$ & Coef. & $\mathrm{SE}$ & $\begin{array}{c}\text { Marginal } \\
\text { effect }\end{array}$ \\
\hline Cons. & $-3.980^{* * *}$ & 0.233 & - & $-4.339^{* * *}$ & 0.294 & - & $-4.792^{* * *}$ & 0.411 & - \\
\hline GOV & $0.363^{* * *}$ & 0.140 & 0.036 & $0.335^{*}$ & 0.174 & 0.031 & 0.161 & 0.241 & - \\
\hline FIN $(t-1)$ & - & - & - & $0.603^{* * *}$ & 0.173 & 0.026 & $0.837^{* * *}$ & 0.232 & 0.020 \\
\hline FIN $(t-2)$ & - & - & - & - & - & - & 0.186 & 0.235 & \\
\hline FOF & $0.342^{* * *}$ & 0.055 & 0.031 & $0.426^{* * *}$ & 0.074 & 0.030 & $0.279^{* * *}$ & 0.103 & 0.027 \\
\hline FOC & $0.136^{* *}$ & 0.056 & 0.016 & $0.162^{* *}$ & 0.073 & 0.014 & $0.239^{* *}$ & 0.105 & 0.011 \\
\hline FOO & -0.028 & $0 . .046$ & - & -0.082 & 0.061 & - & -0.088 & 0.083 & - \\
\hline FOQ & 0.053 & 0.067 & - & 0.034 & 0.053 & - & 0.039 & 0.065 & - \\
\hline FOI & 0.056 & 0.047 & - & 0.044 & 0.061 & - & $0.161^{*}$ & 0.083 & 0.007 \\
\hline $\mathrm{FOH}$ & $0.119^{* *}$ & 0.048 & 0.008 & $0.196^{* * *}$ & 0.062 & 0.008 & $0.277^{* * *}$ & 0.087 & 0.007 \\
\hline IAG & $0.587^{* *}$ & 0.231 & 0.044 & $0.620^{* *}$ & 0.281 & 0.043 & $0.735^{*}$ & 0.382 & 0.039 \\
\hline IMA & $0.892^{* * *}$ & 0.319 & 0.061 & $1.029^{* * *}$ & 0.388 & 0.061 & $1.469^{* * *}$ & 0.512 & 0.057 \\
\hline ICO & 0.258 & 0.241 & - & 0.211 & 0.291 & - & 0.419 & 0.392 & \\
\hline IWH & 0.342 & 0.293 & - & 0.334 & 0.351 & - & $0.793^{*}$ & 0.458 & 0.005 \\
\hline IRE & 0.276 & 0.262 & - & 0.286 & 0.316 & - & 0.660 & 0.422 & - \\
\hline IAC & -0.013 & 0.271 & - & -0.202 & 0.335 & - & -0.021 & 0.446 & - \\
\hline ITR & -0.244 & 0.293 & - & -0.308 & 0.356 & - & -0.389 & 0.485 & - \\
\hline ITE & 0.433 & 0.295 & - & $0.584^{*}$ & 0.352 & - & 0.571 & 0.470 & - \\
\hline IPR & -0.481 & 0.334 & - & -0.434 & 0.411 & - & 0.033 & 0.527 & - \\
\hline ICU & -0.337 & 0.301 & - & -0.401 & 0.369 & - & -0.396 & 0.492 & - \\
\hline IPE & $-0.565^{*}$ & 0.298 & -0.034 & -0.982 & 0.371 & -0.032 & -0.768 & 0.484 & - \\
\hline SIZE & $0.052^{* *}$ & 0.029 & 0.023 & $0.045^{* *}$ & 0.021 & 0.022 & $0.028^{*}$ & 0.021 & 0.024 \\
\hline GRO & $0.663^{* * *}$ & 0.082 & 0.050 & $0.732^{* * *}$ & 0.107 & 0.047 & $0.693^{* * *}$ & 0.144 & 0.047 \\
\hline EXP & $-0.593^{*}$ & 0.355 & -0.063 & -0.529 & 0.466 & - & -0.805 & 0.701 & - \\
\hline Obs. & 10,300 & - & - & 7,235 & - & - & 5,335 & - & - \\
\hline LogL & $782.930^{* * *}$ & - & - & $477.560^{* * *}$ & - & - & $282.890^{* * *}$ & - & - \\
\hline
\end{tabular}

